\title{
Relative Water Transparency and Color in the Northern Part of the Tropical Atlantic
}

\author{
V. I. Man'kovsky*, D. V. Grinchenko \\ Marine Hydrophysical Institute, Russian Academy of Sciences, Sevastopol, Russian Federation \\ *e-mail: emankovskaya@mail.ru
}

\begin{abstract}
By now a large data array, which made it possible to construct maps of the depth distribution of Secchi disk visibility in the World Ocean, has been accumulated. However, the updating of this database remains urgent, since there is not enough data for constructing reliable maps in some areas of the ocean. This is also related to the tropical area of the Atlantic Ocean, in particular. In the present article the statistically reliable maps of depth distribution of Secchi disk visibility $Z_{\text {white }}$ (relative transparency) and water color distribution $\mathrm{N}_{\text {color }}$ in the northern part of the tropical area $\left(0-12{ }^{\circ} \mathrm{N}\right)$ of the Atlantic Ocean in summer and winter are constructed based on the multiannual observational data obtained in 1984-1990. It is shown that the basic features of the fields $\mathrm{Z}_{\text {white }}$ and $\mathrm{N}_{\text {color }}$ are explained by waters dynamics in the indicated region that results in formation of the upwelling and downwelling zones where water transparency decreases and increases, respectively. Here, the largescale currents form two following gyres having different direction: the tropical cyclonic gyre, where an upwelling takes place (divergence zone) and the tropical anticyclonic one, where a downwelling occurs (convergence zone). Also, near the equator, due to a change in the Coriolis force sign, there is a divergence of the South Passat Current, accompanied by the upwelling. The areas where Zwhite $>41 \mathrm{~m}$ were revealed. It is shown that in these areas the anticyclonic vorticity of currents with downwelling was observed. As for the seasonal variability, it was established that In winter water transparency is higher and its color is more intensive than in summer; it is explained by the seasonal variability of currentsand the related water vertical motions.
\end{abstract}

Keywords: tropical area of the Atlantic Ocean, Secchi disk, transparency and color of water, divergence, convergence.

DOI: 10.22449/1573-160X-2017-4-59-65

(C) 2017, V.I. Man’kovsky, D.V. Grinchenko

(C) 2017, Physical Oceanography

Introduction. Relative water transparency is the maximum depth of the Secchi disk standard visibility [1] (denoted by $Z_{w}$ ). The water color is defined in chromacity points applying a special scale (denoted by $N_{\text {col }}$ ) [2]. These hydrooptical features are most easily measured, since they do not require special instruments.

A number of studies indicate that a number of other optical-biological features can be defined from the values of $Z_{\mathrm{w}}$ and $N_{\mathrm{col}}$. Consequently, to study the distributions of $Z_{\mathrm{w}}$ and $N_{\text {col }}$ in different areas of the World Ocean is a crucial task.

In the late $30 \mathrm{~s}$ of the $20^{\text {th }}$ century relative transparency was included in the complex of compulsory oceanographic observations. As a result, a large data array has been currently accumulated, allowing the construction of $Z_{\mathrm{w}}$ distribution maps in the World Ocean [3-5]. However, the problem of the database seeding remains urgent, as it is still not enough for reliable mapping of individual regions of the World Ocean. Thus, in [3], on the distribution map for summer period, $Z_{\mathrm{w}}$ isolines in the western part of the tropical part of the Atlantic Ocean were drawn by a dashed line. It indicates a small amount of observational data and the probable position of the isolines shown. 
What is more, the construction of the trusted $Z_{\mathrm{w}}$ distribution maps is important not only from the geographical viewpoint, but also in terms of studying the relationships of Secchi disk visibility the with various hydrooptical characteristics in the ocean waters. The research in this field, described in a number of papers [612 ], has shown the efficiency of definition of many hydrooptical features by $Z_{\mathrm{w}}$.

The present article involves a large array data on $Z_{\mathrm{w}}$ and $N_{\text {col }}$ in the northern part $\left(0-12^{\circ} \mathrm{N}\right)$ of the tropical Atlantic. It gives possibility to construct statistically reliable maps of the distribution of these features for summer and winter periods.

Study area. In 1984-1990 the research within the program "Sections" were carried out by Marine Hydrophysical Institute. The program was aimed to study the spatial structure of hydrophysical fields and large-scale water circulation in the tropical energy-active zone of the Atlantic Ocean.

In the initial period the studies were carried out at the polygons situated in various parts of the northern part of the tropical Atlantic. Starting from 1986, the works were performed at the same transoceanic polygon $\left(1^{\circ} \mathrm{S}-12^{\circ} \mathrm{N}, 14-55^{\circ} \mathrm{W}\right)$ along a single grid of stations: the meridional sections were located at the distance of $1.5^{\circ}$ between each other longitudinally, the stations on sections - at distance of $0.5^{\circ}$ latitudinally.

At all the stations, the relative water transparency $Z_{\mathrm{w}}(\mathrm{m})$ and its color $N_{\mathrm{col}}$ (points) were measured according to a standard color scale [2]. $Z_{\mathrm{w}}$ and $N_{\text {col }}$ distribution maps were constructed within the transoceanic polygon on the basis of this data.

Methodology of Map Construction. Fig. 1 shows the location of $Z_{\mathrm{w}}$ and $N_{\text {col }}$ measurement points in spring-summer (April - September) and autumn-winter (October - March) periods. The first period will be called summer, the second winter one. In total, 507 measurements were carried out in summer and 365 in winter period.

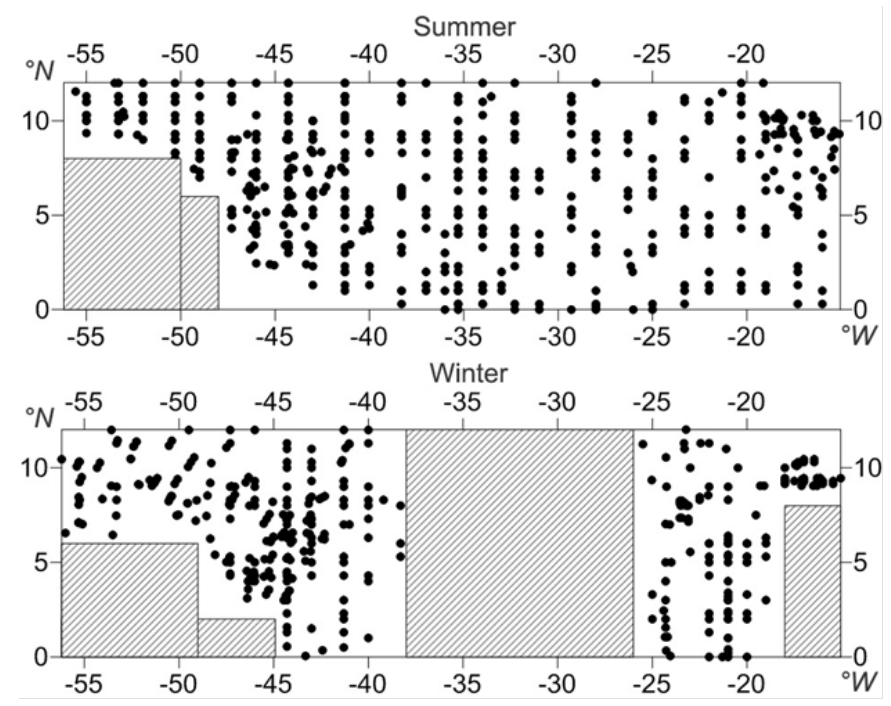

Fig. 1. Location of stations where observations of $Z_{\mathrm{w}}$ and $N_{\mathrm{col}}$ were carried out 
To construct the maps, the area was divided into $2 \times 2^{\circ}$ squares, where averagely 5 observations were performed in summer and in winter. In the squares, the mean values of $Z_{\mathrm{w}}$ and $N_{\mathrm{col}}$ are calculated, which the corresponding maps have been constructed on.

Results and their Discussion. Fig. 2 and 3 show $Z_{\mathrm{w}}$ and $N_{\text {col }}$ distribution maps in various seasons of the year. The main features of the distribution of these features are accounted for by the dynamics of waters in the Tropical Atlantic [13].

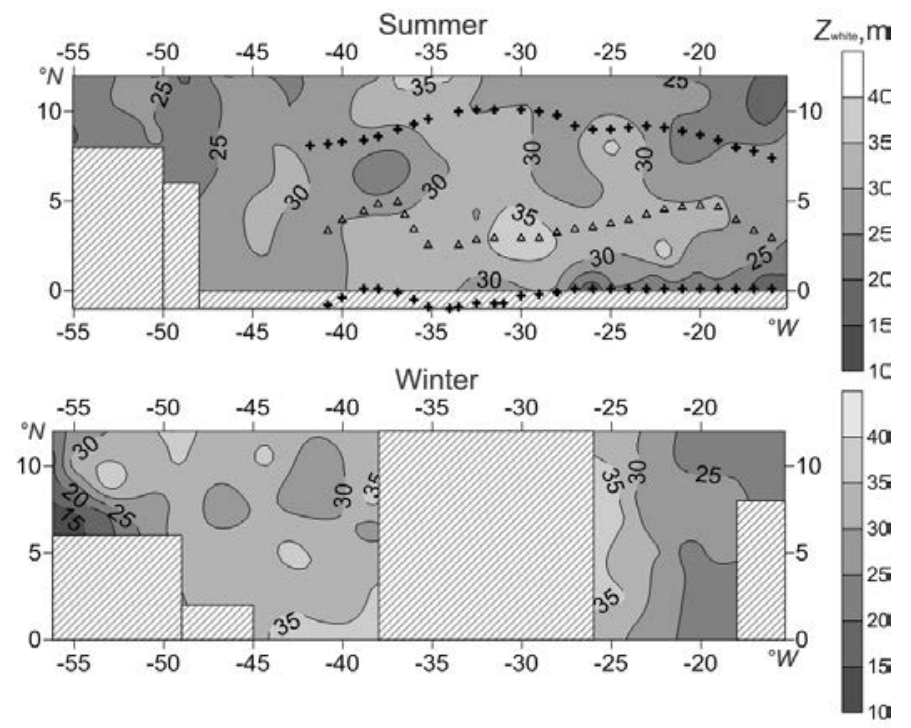

Fig. 2. Distribution of $Z_{\mathrm{w}}$ in summer and winter. Position of the zones of vergences is shown: crosses - zones of tropical and equatorial divergences, triangles - a zone of tropical convergence

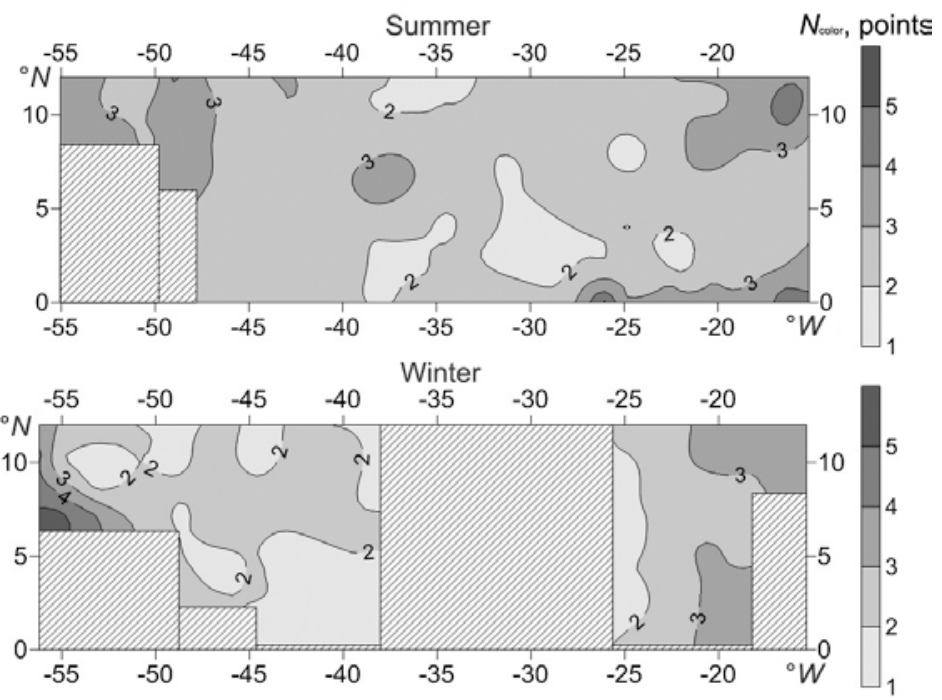

Fig. 3. Distribution of $N_{\text {col }}$ in summer and winter

PHYSICAL OCEANOGRAPHY ISS. 4 (2017) 
Here large-scale currents form quasistationary cyclonic and anticyclonic gyres, within which, the water rises and sinks, respectively. Two multidirectional largescale gyres are formed in the considered areas: Tropical cyclonic, composed of the northern part of the Betweenpassat Counter Current and the Northern Passat Current; Tropical anticyclonic, the components of which are the southern part of the Betweenpassat Counter Current and the South Passat Current.

There is a specific area near the equator as well, where, due to a change in the Coriolis force sign, the South Passage Current divergence accompanied by water upwelling occurs.

In the upwelling zones, biogenic substances are transported from the depths to the surface layers, which leads to an increase in the concentration of phytoplankton in them and, accordingly, to a decrease in the water transparency. In the downwelling zones, the reverse picture is observed - due to the low concentration of nutrients in the surface layers, the concentration of phytoplankton in them is low, which results in high water transparency.

The water color changes with the variation of $Z_{\mathrm{w}}$ in inverse relation - as the $Z_{\mathrm{w}}$ decreases, the $N_{\text {col }}$ color point increases.

Fig. 2 shows (according to [13], Fig. 42) the position of the vergence zones: the divergence zone (water upwelling) in the Tropical cyclonic gyre; the convergence zone (water downwelling) in the Tropical anticyclonic gyre; the equatorial divergence zone in the South Passat Current. It is seen that in the divergence zones $Z_{\mathrm{w}}$ is much lower than in the convergence zone. The mean value of $Z_{\mathrm{w}}$ in the equatorial divergence zone was $22 \mathrm{~m}$, in the divergence zone of in the Tropical cyclonic gyre $-28 \mathrm{~m}$ and in the convergence zone in the Tropical anticyclonic gyre $-32 \mathrm{~m}$.

The lower values of $Z_{\mathrm{w}}<20 \mathrm{~m}$ in the extreme western part of the polygon result from the removal of turbid waters in the Amazon River, which enter the Guane Current (equator area around $49^{\circ} \mathrm{W}$ ), and along with it are transported in the northwestern direction along the South America coasts.

The values of $Z_{\mathrm{w}}<20 \mathrm{~m}$ in the northeastern part of the polygon are caused by water upwelling as a result of the divergence of the Betweenpassat Counter Current occurring in this area, which was divided into two branches extending in the northeast and east directions [14].

Fig. 2 shows that in winter the transparency of the waters in the studied tropical area is higher. Tab. 1 presents the mean values of $Z_{\mathrm{w}}$ and $N_{\text {col }}$ for the areas where observations were carried out in summer and winter.

T able 1

Mean Values of $Z_{\mathrm{w}}$ and $N_{\text {col }}$

\begin{tabular}{c|c|c|c|c}
\hline \multirow{2}{*}{ Район } & \multicolumn{2}{|c|}{$\left\langle Z_{\mathrm{w}}\right\rangle, \mathrm{m}$} & \multicolumn{2}{c}{$\left\langle N_{\text {col }}\right\rangle$, points } \\
\cline { 2 - 5 } & summer & winter & summer & winter \\
\hline $\begin{array}{c}14-26^{\circ} \mathrm{W}, \\
0-12^{\circ} \mathrm{N}\end{array}$ & 27 & 28 & 3 & 3 \\
$\begin{array}{c}38-56^{\circ} \mathrm{W}, \\
0-12^{\circ} \mathrm{N}\end{array}$ & 27 & 32 & 3 & 2 \\
\hline
\end{tabular}


The increase in the water transparency in winter was observed in both regions, but to varying degrees: in the eastern area it was $1 \mathrm{~m}$ in comparison with the summer and $5 \mathrm{~m}$ in the western one. This was also manifested in the change in the water color: in the eastern area it practically did not change: $\left\langle N_{\text {col }}\right\rangle_{\text {summer }}=3$ (blue), $\left\langle N_{\text {col }}\right\rangle_{\text {winter }}=3$ (blue), in the western area the water turned blue: $\left\langle N_{\text {col }}\right\rangle_{\text {summer }}=$ $=3$ (blue), $\left\langle N_{\text {col }}>_{\text {winter }}=2\right.$ (dark blue).

The water transparency increase in winter can be explained by the seasonal variability of water dynamics in the tropical area.

In winter period, the Northern Passat Current weakens, and the South Passat Current gets stronger [13]. As a result, the Tropical cyclonic gyre becomes weak, and the Tropical anticyclonic gyre intensifies. Thus, in winter in the cyclonic gyre the water upwelling weakens, i.e. as compared with summer, the transparency in it increases. In the anticyclonic gyre, the water downwelling intensifies in winter and, in comparison with summer, the transparency also increases.

Presence of the waters with $Z_{\mathrm{w}}>35 \mathrm{~m}$ in winter in the area of $25^{\circ} \mathrm{W}$ is due to the seasonal variability of the circulation in the Tropical Atlantic. According to [15], in autumn period, the Betweenpassat Counter Current in the eastern part of the polygon forms a large-scale anticyclonic meander covering the area $2-11^{\circ} \mathrm{N} ; 23-31^{\circ} \mathrm{W}$ (the meander center is situated near $7^{\circ} \mathrm{N} ; 28^{\circ} \mathrm{W}$ ).

Fig. 2 and Tab. 1 show the mean values of $Z_{\mathrm{w}}$. The maximum values of the water transparency are shown in Tab. 2.

Table 2

Values of $Z_{w}>40 \mathrm{~m}$ Fixed at the Polygon

\begin{tabular}{c|c|c|c|c|c|c}
\hline \multirow{2}{*}{$Z_{\mathrm{w}}, \mathrm{m}$} & \multirow{2}{*}{$\begin{array}{c}N_{\text {col, }} \\
\text { points }\end{array}$} & \multicolumn{2}{|c|}{ Coordinates } & \multirow{2}{*}{ Date } & $R / V$ No. & \multirow{2}{*}{ Season } \\
\cline { 3 - 4 } & 2 & $W$ & & & \\
\hline 44 & 2 & $8^{\circ} 00^{\prime}$ & $50^{\circ} 54^{\prime}$ & 17 Aug 83 & $30 \mathrm{AV} *$ & Summer \\
42 & 2 & $2^{\circ} 39^{\prime}$ & $45^{\circ} 28^{\prime}$ & 10 Jul 85 & $32 \mathrm{AV}$ & Summer \\
41 & 2 & $5^{\circ} 12^{\prime}$ & $44^{\circ} 40^{\prime}$ & 06 Apr 83 & $30 \mathrm{AV}$ & Summer \\
46 & 2 & $7^{\circ} 00^{\prime}$ & $44^{\circ} 30^{\prime}$ & 05 Jul 87 & 36 AV & Summer \\
44 & 2 & $4^{\circ} 57^{\prime}$ & $40^{\circ} 11^{\prime}$ & 25 Jul 85 & 32 AV & Summer \\
41 & 3 & $3^{\circ} 00^{\prime}$ & $36^{\circ} 00^{\prime}$ & 21 Jul 85 & 32 AV & Summer \\
41 & 3 & $1^{\circ} 00^{\prime}$ & $35^{\circ} 30^{\prime}$ & 08 Jun 87 & 36 AV & Summer \\
42 & 2 & $4^{\circ} 30^{\prime}$ & $34^{\circ} 00^{\prime}$ & 06 Jun 87 & 36 AV & Summer \\
41 & 3 & $3^{\circ} 00^{\prime}$ & $31^{\circ} 00^{\prime}$ & 08 Sept 86 & 47 ML & Summer \\
46 & 2 & $9^{\circ} 13^{\prime}$ & $52^{\circ} 14^{\prime}$ & 19 Feb 83 & 30 AV & Winter \\
45 & 2 & $5^{\circ} 00^{\prime}$ & $47^{\circ} 30^{\prime}$ & 01.Oct 86 & 34 AV & Winter \\
42 & 2 & $4^{\circ} 30^{\prime}$ & $47^{\circ} 30^{\prime}$ & 01 Oct 86 & 34 AV & Winter \\
45 & - & $9^{\circ} 01^{\prime}$ & $24^{\circ} 26^{\prime}$ & 28 Feb 70 & 24 ML & Winter \\
\hline
\end{tabular}

*N o t e. AV - R/V Akademik Vernadsky, ML - R/V Mikhail Lomonosov

The values of $Z_{\mathrm{w}}$ equal to $41-42 \mathrm{~m}$ in the area of $3-4^{\circ} 30^{\prime} \mathrm{N}$; $31-36^{\circ} \mathrm{W}$, fall on the convergence zone (Fig. 2). 
In summer in the western part of the polygon near $2^{\circ} 39^{\prime}-7^{\circ} \mathrm{N} ; 40^{\circ} 11^{\prime}-$ $45^{\circ} 28^{\prime} \mathrm{W}$ the value of $Z_{\mathrm{w}}$ equal to $41-46 \mathrm{~m}$ were monitored, According to [15], in spring there is an anticyclonic movement of waters in the area of $3-8{ }^{\circ} \mathrm{N}$; $37-45^{\circ} \mathrm{W}$.

In winter the value of $Z_{\mathrm{w}}$ equal to $45 \mathrm{~m}$ was observed near $9^{\circ} 01^{\prime} \mathrm{N} ; 24^{\circ} 26^{\prime} \mathrm{W}$, where in the autumn season, the Betweenpassat Counter Current forms a largescale anticyclonic meander [15].

A comparison of $Z_{\mathrm{w}}$ distribution in the Tropical Atlantic with the data of [3] was also carried out. The order of magnitude of $Z_{\mathrm{w}}$ distribution in the central areas of the considered polygon in summer and winter is the same (25-35 m) according to the data of the present work and the data of [3].

It is not possible to compare the values by the seasons, since in [3] on the map of the tropical Atlantic westward of $20^{\circ} \mathrm{W} \mathrm{Z} Z_{\mathrm{w}}$ isolines for summer period are dotted, indicating their probable position.

\section{Conclusions}

1. The maps of relative water transparency and color distribution in the northern part of the tropical area $\left(0-12^{\circ} \mathrm{N}\right)$ of the Atlantic Ocean in summer and winter are constructed based on the observational data obtained in 1984-1990.

2. The main features of the transparency field are accounted for by the dynamics of the waters of the studied area.

3. In winter water transparency is higher and its color is more intensive than in summer. This can be explained by the seasonal variability of currents and the related water vertical motions.

\section{REFERENCES}

1. Kozlyaninov, M.V., 1961. Rukovodstvo po Gidroopticheskim Izmereniyam v More [Hydrooptical Sea Measurement Guidance]. In: IO AN USSR, 1961. Trudy IOAN SSSR [Proceedings of IO AN USSR]. Vol. XLVII, pp. 37-79 (in Russian).

2. Soskin, I.M., 1967. Rukovodstvo po Gidrologicheskim Rabotam v Okeanakh i Moryakh [Guidance on Hydrological Works in Seas and Oceans]. Leningrad: Gidrometeorologicheskoe izdatel'stvo, 554 p. (in Russian).

3. Monin, A.S. ed., 1983. Optika Okeana. Prikladnaya Optika Okeana [Ocean Optics. Applied Ocean Optics]. Moscow: Nauka. Vol. 2, pp. 21-26 (in Russian).

4. Shifrin, K.S., 1978. Fizika Oceana. T.2. Gidrofizika Okeana (Seriya “Okeanologiya”) [Ocean Physics. Vol. 2. Ocean Hydrophysics (Oceanology series)]. Moscow: Nauka, pp. 359-365 (in Russian).

5. Ivanov, A.A., 1978. Vvedenie v Okeanografiyu [Introduction to Oceanology]. Moscow: Mir, pp. 382-391 (in Russian).

6. Pilgram, D.A., 1984. The Secchi Disk in Principle and in Use. Hydrograph. J., (33), pp. 25-30.

7. Graham, J.J., 1966. Secchi Disk Observations and Extinction Coefficients in the Central and Eastern North Pacific Ocean. Limnol. Oceanogr., [e-journal] 11(2), pp. 184-190. Available at: http://citeseerx.ist.psu.edu/viewdoc/download?doi=10.1.1.488.2974\&rep=rep1\&type=pdf [Accessed 20 July 2017].

8. Kullenberg, G., 1980. Relationships between Optical Parameters in Different Oceanic Areas. In: Københavns universitet. Institut for fysisk oceanografi, 1980. Studies in Physical Oceanography: Papers Dedicated to Professor Nils G. Jerlov in Commemoration of His Seventieth Birthday. Copenhagen: Institute of Physical Oceanography, University of Copenhagen. Report No. 2, pp. 57-79. 
9. Aas, E., 1980. Relation between Total Quanta Blue Irradiance and Secchi Disc Observations in the Norvegian and Barents Seas. In: Københavns universitet. Institut for fysisk oceanografi, 1980. Studies in Physical Oceanography: Papers Dedicated to Professor Nils G. Jerlov in Commemoration of His Seventieth Birthday. Copenhagen: Institute of Physical Oceanography, University of Copenhagen. Report No. 2, pp.11-27.

10. Matciak, M., 1997. Estimation of the Attenuation of Visible Light in Waters of the Gulf of Gdansk with the Use of Secchi Transparency. Ocean. Stud., [e-journal] XXVI(4), pp. 35-40. Available at: http://model.ocean.univ.gda.pl/description/Papers/Matciak\%20M._Estimation\%20of\%20attan uation....pdf [Accessed 20 July 2017].

11. Man'kovsky, V.I., 1978. Empiricheskaya Formula dlya Otsenki Pokazatelya Oslableniya Sveta v Morskoy Vode po Glubine Vidimosti Belogo Diska [Empirical Formula for Light Attenuation Index Estimation in Sea Water from the Depth of Secchi Disk Visibility]. Oceanology, 18(4), pp. 750-753 (in Russian).

12. Man'kovsky, V.I., 2014. Svyaz' Pokazatelya Vertikal'nogo Oslableniya Dnevnogo Sveta s Glubinoy Vidimosti Belogo Diska [The Relationship between the Indicator of the Vertical Attenuation of Daylight and the Depth of Secchi Disk Visibility]. Oceanology, [e-journal] 54(1), pp. 37-43 (in Russian). doi:10.7868/S0030157414010080

13. Hlystov, N.Z., 1976. Struktura i Dinamika Vod Tropicheskoy Atlantiki [Structure and Dynamics of the Tropical Atlantic Waters]. Kiev: Naukova dumka, pp. 103-122 (in Russian).

14. Artamonov, Yu.V., Polonsky, A.B. and Pereyaslavsky, M.G., 1987. Issledovanie Krupnomasshtabnoy Tsirkulyatsii Vod v Severo-vostochnoy Chasti Tropicheskoy Atlantiki [The Study of Large-scale Water Circulation in the Northeastern Part of the Tropical Atlantic]. Deposited Manuscript, No. 391-887. Moscow: VINITI, 25 p. (in Russian).

15. Artamonov, Yu.V., Bulgakov, N.P., Ivanov, V.F. and Polonsky, A.B., 1991. Sezonnaya Izmenchivost' Tsirkulyatsii Vod Severnoy Chasti Tropicheskoy Atlantiki [Seasonal Variability of Water Circulation in the Northern Part of the Tropical Atlantic]. Sevastopol: MHI AS SSSR, 29 p. (in Russian). 